子の質量流量, 圧力損失の測定を行い, 従来の冷 水の顕熱輸送法より有利となることを確認してい る。

\section{5.あとがき}

以上の実験より，氷粒子を空気によって搬送す ることが可能で, その体積流量混合比は, 従来の 冷水の顕熱輸送方式より, 動力損失を小さくする ことができる目標值 0.05 を満足できることが分 かった。水粒子の搬送は，プラグ流に近い状態で 流すほど高密度に粒子を送れて効果的であるが, その場合水粒子の閉塞が起こることもある。しか しこの閉塞の解除方法として, 圧搾空気を搬送パ イプ内に局所的に注入する方法が有効であること あ分かった。

\section{文献}

1) 吉田 崇, 笹尾博行; 空気調和・衛生工学会学術 講演会講演論文集, p.401 p.404（'93年10月20～22日）

2 ) 柳原隆司; 水蓄熱空調システムの経済性, 冷凍, 特集 “承蓄熱技術”，62,（715），31（1987）

3 ）坪田祐二, 梁取美智雄, 黒崎晏夫, 佐藤 勲 ; 水 の空気搬送技術，冷凍，68，(794)，61（1993）

4 ）黑崎晏夫, 佐藤 勲, 安井元一 ; 第 26 回日本伝熱 シンポジウム講演論文集, p.851〜p.853(1989年5月)

5) Y. Kurosaki, I. Satoh, M. Yasui ; Experimental Heat Transfer, Fluid Mechanics and Thermodynamics 1991, p.1177 p.1184 (Elsevier Science Publishing Co. Inc., 1991)

(1994-10-31 受理)

\title{
小特集 “省エネ・省資源よ表面処理”によせて
}

地球環境改善の一環として地球温暖化防止対 策のため「省エネ法」の改正（平成 5 年 3 月） により関連法案が整備され, 実質的に平成 5 年 8 月より施行されて日本であ本格的な取組みが スタートした。その主な骨格はエネルギー管理 指定工場の届け出義務およびエネルギー原単位 管理（生産額あるいは生産量当たりのエネルギー 使用量）の導入であり，年 $1 \%$ 以上改善努力 義務が課せられることとなった。

一方, 近年の構造不況, 円高為替変動の嵐の 中で製造業の国内外での価格競争は激化してお り，表面処理の分野においても材料・プロセス， 設備, ランニングコストなどの面において大幅 な見直しと対策がせまられている。

このような状況の中で, 今回 “省エネ・省資 源”の観点加ら表面処理を考える必要性を強く 感じて企画することとなり, 主として表面処理
のそれぞれの分野で実際に対策を講じている企 業の方々に既に実施している事柄や今後の取組 みについて解説していただいた。その内容の多 くはKnow-Howに近い貴重なデータや実施例 であり，また御多忙の中を御執筆いただきこ の場をおかりして改めて深く御礼申し上げます。

この小特集を基として，協会会員の皆様に今 後の省エネ・省資源対策，さらには低コストプ ロセスの開発に少しでもお役に立てれば幸いで क。

\section{（寺門 一佳）}

\section{〔本小特集企画委員〕}

小泉 宗栄（日本パーカライジング侏）

小谷勇 (愛知県工業技術センター)

龊木 邦夫（東芝タンガロイ(柈）

寺門 一佳（侏）日立製作所）

馬飼野信一（神奈川県工業試験所） 